\title{
Impact of COVID-19 on Food Systems and Rural Livelihoods in Tanzania
}

\author{
COVID-19 Country Report 2 - December 2020 Prepared by Gideon Boniface and C.G. Magomba
}

\section{Introduction}

On 8 June 2020, the Government of Tanzania officially declared the country to be free of COVID-19 and all restrictions have since been lifted. As of 3 December 2020, Tanzania had only 509 confirmed cases of the virus and 21 deaths. ${ }^{1}$ Nevertheless, neighbouring countries are still facing the threat of the pandemic, all of which are key trading partners. Their continuing COVID-19 control measures have disrupted regional and domestic agricultural markets and affected local livelihoods and food systems. This study analysed the resulting impacts in those systems in several rice-producing communities in Morogoro Region, south-western Tanzania.

\section{Context}

This study is a follow up to the first round (R1) rapid assessment, which took place in mid-July 2020 on the real-time impact of the COVID-19 crisis on rural livelihoods and food systems in the villages of Chita, Makutano, Mchombe, Mkusi and Njage in Mlimba District. For the second study (R2), phone interviews were conducted in October and November 2020 with 98 farmers (46 female-; 54 male-headed households) selected from a stratified random sample, together with five key informants, who participated in R1, two new farmers and two other local officials.

\section{Health and disease}

All respondents reported that no member of their household had shown any COVID-19 symptoms nor were they aware of any confirmed cases in their villages, similarly to R1. About $97 \%$ of respondents said they were able to access health services since the relaxation of restrictions on movement. Fear with regards to COVID-19 had significantly decreased and many did not consider it a serious threat to their health or wellbeing.

"Despite the fact that rice is mainly a cash crop, this year rice has become more of a food crop as we still have rice in our houses and stores. We have not sold enough to cover our costs and we don't know when we will sell it." - Secretary of Village Rice Committee, Njage Village

\section{Farm labour and marketing}

The majority of farmers (64\%) said they were able to hire casual labour. More than half (53\%) of respondents also confirmed a decrease in the cost of labour, 30\% said the cost had remained unchanged, and $5 \%$ stated that it had increased. However, a significant number of farmers reported a decrease in their ability to sell their produce at the farmgate (70\%) and at their local market $(60 \%)$. They explained that this decrease was largely the result of a massive reduction in the number of external buyers/

1 Tanzania Country Overview. Johns Hopkins Coronavirus Resource Center - bit.ly/3gCpmB8

\section{Key findings}

- $64 \%$ of respondents said they did not comply with the government's COVID-19 guidelines.

- Only $7 \%$ and $6 \%$ of respondents reduced their movement within and outside their villages, respectively, following the start of the COVID-19 threat.

- Major staple foods are available, and their prices have gone down or remain unchanged, but $27 \%$ of respondents perceived themselves as food insecure.

- $71 \%$ of respondents experienced an increase in the overall cost of living, and 58\% deemed that their living standards had worsened since the start of the crisis.

- Concerns for the upcoming agricultural season had increased as farmers' purchasing power had decreased.

- The price of paddy/rice, which is a major cash crop, had fallen compared to last year, as the number of buyers had decreased significantly, leading to a drop in household incomes.

- Labour and other inputs for production were available and their cost remained unchanged to a large extent, but their accessibility for many farmers was limited.

traders who visit local farms and markets, a situation that has caused an over-supply of rice and, consequently, a decline in the price of paddy/rice. This has led to a drop in the revenue for other actors in the rice value chain, including small-scale transporters, who provide transport services to producers and traders, and haul rice/paddy from rural areas to local market centres and processing facilities.

\section{Availability of services for agricultural production} Although $11 \%$ of respondents reported an increase in the availability of inputs for agricultural production, $76 \%$ stated that

Figure 1: Availability and price of grains

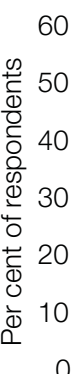

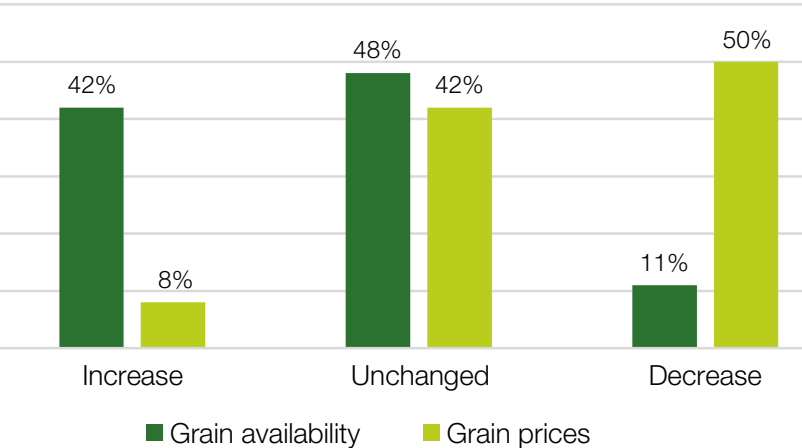


it remained unchanged, and 9\% said it had decreased. Furthermore, the majority (69\%) of respondents reported that the price of inputs had remained unchanged in the previous quarter, although 24\% reported an increase in their input prices. Other means of production and services (rental land for agriculture and tillage services) were reported to be available and prices remained largely unchanged or had decreased, but the ability of farmers to access them was reported to have declined significantly.

\section{Food and nutrition security}

The availability of grains (a major staple food in local diets) had increased for $41 \%$ of respondents since R1, while $48 \%$ stated that availability remained largely unchanged. Only $11 \%$ reported decreased availability. About half of respondents confirmed that grain prices had decreased, $42 \%$ reported that prices were unchanged and $8 \%$ encountered an increase in grain prices.

Amid an increase in availability and a decrease in prices of most food stuffs, $66 \%$ of respondents expressed concern about having enough food for their households due to a lack of money and other resources. Some $71 \%$ stated that decreased income meant they were unable to eat healthy and nutritious foods over the previous quarter and were only able to eat a limited variety of several major food groups. Overall, $27 \%$ of respondents described themselves as being food insecure. Female-headed households were more than twice as likely to place themselves in this category as male-headed households $(39.1 \%$ versus $16.0 \%)$, highlighting important gendered impacts of the crisis.

\begin{tabular}{|l|c|}
\hline \multicolumn{1}{|c|}{ Experience } & Respondents \\
\hline Worried about inadequate food & $66 \%$ \\
\hline Unable to eat healthy foods & $71 \%$ \\
\hline Ate only a few food types & $71 \%$ \\
\hline Skipped meals & $28 \%$ \\
\hline Ate less & $35 \%$ \\
\hline Ran out of food & $15 \%$ \\
\hline Hungry but no food to eat & $17 \%$ \\
\hline No eating for the whole day & $1 \%$ \\
\hline Food not adequate for family & $30 \%$ \\
\hline
\end{tabular}

\section{Responses to the threat of COVID-19}

Access to agricultural advisory services, such as extension agents, has increased among farmers since R1. Now that limits on social gatherings have been removed, farmers are free to attend to their fields and meet in groups. Few respondents reported that they have reduced their movement within (7\%) or outside (6\%) of their villages because of COVID-19. Transportation of people and goods continues to take place. However, the number of traders or buyers coming to the area to purchase paddy has decreased significantly (20-30\% of usual levels), leading to a drop in farmgate prices. Farmers say they are unwilling to sell all of their stock because they fear they might become food insecure, so are only selling enough to meet their cash needs.

Local traders and shops have stopped selling hand soap, sanitiser, buckets and face masks. Their earnings from the sale of these goods have declined and some have realised big losses as demand has waned after the removal of COVID-19 restrictions and active promotion of safe hygiene behaviour.

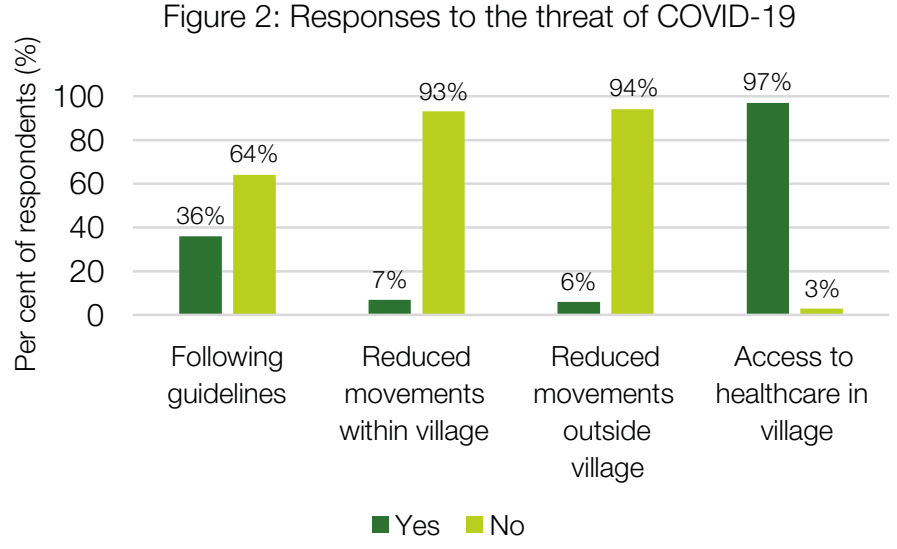

Boniface, G. and Magomba, C.G. (2020) Impact of COVID-19 on Food Systems and Rural Livelihoods in Tanzania. Round 2 - December 2020, APRA COVID-19 Country Report, Brighton: Future Agricultures Consortium

(c) APRA 2020

ISBN: 978-1-78118-742-5

DOI: 10.19088/APRA.2020.020

This is an Open Access report distributed under the terms of the Creative Commons Attribution Non Commercial No Derivatives 4.0 International licence (CC BY-NC-ND), which permits use and distribution in any medium, provided the original authors and source are credited, the work is not used for commercial purposes, and no modifications or adaptations are made.

If you use the work, we ask that you reference the APRA website (www.future-agricultures.org/apra/) and send a copy of the work or a link to its use online to the following address for our archive: APRA, Future Agricultures, University of Sussex, Brighton BN1 9RE, UK (apra@ids.ac.uk)

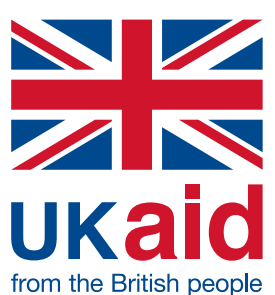

This report is funded with UK aid from the UK government (Foreign, Commonwealth \& Development Office - FCDO, formerly DFID). The opinions are the authors' and do not necessarily reflect the views or policies of IDS or the UK government. 